\title{
近年の沖縄県における木造住宅生産に関する研究 WOODEN HOUSE PRODUCTION SYSTEM IN RECENT OKINAWA PREFECTURE
}

\author{
権藤智之*，上橋由寛**, 松村秀一*** \\ Tomoyuki GONDO, Yoshihiro UEHASHI and Shuichi MATSUMURA
}

\begin{abstract}
In Okinawa, new wooden house construction starts is very small compared with in the whole Japan. So, wooden house builders in Okinawa have many difficulties, like shortage of lumbers or carpenters. But, from the 1990s, pre-cut lumber shipped from southern Kyushu area have got used in Okinawa. With this new building method, some companies which have no experience of wooden construction moved onto wooden house construction. Most of them build small numbers of wooden houses, and do another business on the other hand. And wooden house building system is influenced by limited distribution channel as well as environmental factor.
\end{abstract}

Keywords : Wooden house, Okinawa prefecture, Pre-cut, Small wooden house builders, Carpenter, Lumber 木造住宅，沖縄県，プレカット，工務店，大工，木材

1. はじめに

\section{1 研究の背景}

沖縄県の人口当たりの木造住宅着工数は、日本全体と比較して極 端に少ない。その原因や結果として、大工などの施工技術者の不足 や木材をはじめとする材料の不足など、木造住宅生産を行うに当た っての様々な課題が存在している。さらに沖縄県では台風などの環 境条件も他地域に比べて襒しく、住宅には高い耐久性が求められる。

一方で別の見方をすれば、そのような条件の厳しい沖縄県におい ても木造住宅生産が少ないながら継続的に行われており、そこには 他地域にはない住宅生産者の取り組みや木造住宅の技術的な特徴が 見られることも予想される。また、プレカット加工などの近年の木 造住宅における技術変化は大きく、沖縄県の木造住宅生産もこうし た近年の変化から何らかの影響を受けていると考えられる。しかし、 近年の沖縄県の木造住宅生産に関する既往の知見は希少である。

\section{2 研究の目的}

本研究の目的は、近年の沖縄県における木造住宅生産の実態を住 宅生産者の活動に着目して明らかにすることである。具体的には、 工務店や設計事務所がどのような木造住宅生産活動を行なっている か、その過程で材料や施工技術者の確保にどういった課題を抱えて いるか、彼らが供給する木造住宅はどのような技術的特徴をもつか、 の 3 点を明らかにすることを目的としている。

\section{3 研究の方法}

2008 年 12 月、 2009 年 2 月、 3 月の 3 回にわたって、沖縄本島の
工務店 16 社・設計事務所 4 社を対象とし、事業内容や、技術者・材 料面での課題、木造住宅の技術的特徴について、聞き取り調査・資 料収集を行った。沖縄本島を対象地域として選定したのは、単一島 内であれば、気候特性や木材をはじめとする建築資材の流通条件が 一様だと考えられるためである。対象とした木造住宅生産者 20 社の 2007 年度の木造戸建住宅着工数を合計すると 100 棟程度となり、沖 縄県全体の木造戸建住宅着工数の約 7 割（沖縄本島の約 8 割）を把 握したことになる注1)。

加えて、沖縄県庁、木材協会、森林組合等の木造住宅生産に関連 する主体や、沖縄県にプレカット材を供給する宮崎県・鹿児島県の プレカット工場 4 社に対する聞き取り調査を行った。

\section{4 既往研究と本研究の位置づけ}

特定地域の木造住宅生産については、1980 年代を中心に多くの調 查、研究が行われている。具体的には、木造住宅生産に関わる工務 店の事業内容や彼らを中心とした専門工事業者のネットワーク、地 域特有の木造住宅仕様などについて明らかにされている $\left.{ }^{2)} 3\right)$ 。また 近年は、効率的な資源循環を意図して、地域産材を利用した木造住 宅生産における物や情報の流れを分析した研究も行われている ${ }^{4)}$ 。

沖縄県の木造住宅生産についても、伝統的な木造住宅生産に用い られた大工技能や材料を明らかにした研究 ${ }^{5)}$ や、農学分野で木材利 用との関係から論じた近年の研究がある ${ }^{6)}$ 。しかし、沖縄県を木造 戸建住宅着工数が極めて限られる特徴的な地域として捉え、悉皆調 査に近いかたちで近年の木造住宅生産者の特徴や住宅技術のあり様 を具体的に把握・分析した既往の知見はない。本研究は特定地域を

\footnotetext{
* 東京大学大学院工学系研究科建築学専攻 大学院生・修士 (工学)

** 東京大学大学院工学系研究科建築学専攻 大学院生

*** 東京大学大学院工学系研究科建築学専攻 教授. 工博

Graduate Student, Dept. of Architecture, Graduate School of Engineering, University of Tokyo, M. Eng.

Graduate Student, Dept. of Architecture, Graduate School of Engineering, University of Tokyo

Prof., Dept. of Architecture, Graduate School of Engineering, University of Tokyo, Dr. Eng.
} 
対象とした木造住宅生産に関する研究の 1 つと位置付けられ、対象 地域の特殊性と、対象とした木造住宅生産者の悉皆性をその特徵と している。

\section{2. 沖縄県の木造住宅生産に関係する統計データの検討 \\ 2. 1 木造住宅着工数の推移}

現在の沖縄県の戸建住宅着工数を見ると、木造住宅が日本全体と 比べて極めて少なく、鉄筋コンクリート（以下 RC）造住宅が極めて 多い（表 1)。2007 年度の沖縄県の木造戸建住宅着工数は 146 戸で、 戸建住宅着工数に占める割合は $6.6 \%$ に過ぎない。一方、日本全体 では同戸数が 375,285 戸、同割合 $85.3 \%$ と大きな割合を占める。

表 12007 年度戸建住宅着工数注 2$)$

\begin{tabular}{|c|c|c|}
\hline & 全国 & 沖縄 \\
\hline 新築戸建住宅の戸数 & 439743 & 2204 \\
\hline 新築木造戸建住宅の戸数 & 375285 & 146 \\
(新築戸建住宅に占める割合) & $(85.3 \%)$ & $(6.6 \%)$ \\
\hline 新築 RC 造戸建住宅の戸数 & 5255 & 1524 \\
(新築戸建住宅に占める割合) & $(1.2 \%)$ & $(69.1 \%)$ \\
\hline
\end{tabular}

沖縄県でも、戦前は木造住宅が住宅生産の主流だった。しかし、 復興期に安価な材料を用いて簡易な工法で建設された木造住宅が台 風や白蟻によって大きな被害を受ける。その一方で、基地建設のた めに整備・育成された RC 系の材料供給体制や設計・施工技術者が民 間工事でも活用され、コンクリートブロック造や RC 造住宅が急速に 普及した。そして、1961 年度には住宅着工数に占める木造住宅と非 木造住宅の割合が逆転し注 3)、1981 年度には、年間木造戸建住宅着 工戸数が 40 戸にまで落ち込んだ注 ${ }^{4)}$ 。

一方、近年の戸建住宅着工数を見ると、 RC 造は 1988 年度から 2007 年度の 20 年間に $50 \%$ 程度減少したのに対し、木造は $10 \%$ 程度増加 しており、戸建住宅着工数に木造が占める割合は近年、増加に転じ ている注5)。

また、木造住宅の構法別着工数の推移注 6) を見ると、近年、枠組 壁構法住宅の着工数が減少し、軸組構法住宅の着工数が増加してい る（図 1)。これは後述するように、沖䋲県でも 1990 年代後半から プレカット工法が普及し、大工が少ない沖縄県でも木造軸組住宅生 産が行いやすくなったためと考えられる。

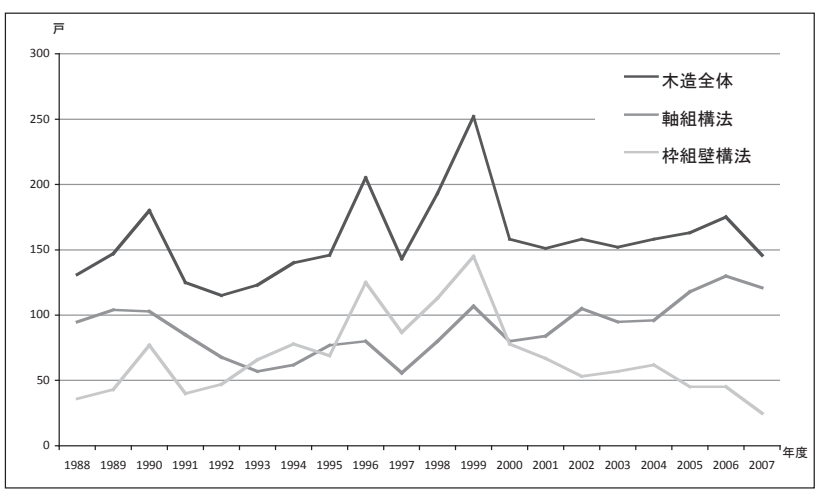

図 1 沖縄県の木造戸建住宅構法別着工数の推移

\section{2 木造住宅生産に関わる施工技術者・材料}

沖縄県では、大工技能者数や木造建築工事業の事業所数が日本全 体と比較して少ない。沖縄県の大工技能士合格者数は 2009 年 3 月ま での累計で 222 人と、全国の累計 179,350 人（2007 年 3 月時点）を 大きく下回り、人口当たりでは全国の 9 分の 1 程度である注7)。また、 木造建築工事業の事業所数は 18 事業所と、人口当たりの事業所数が 日本全体の 50 分の 1 以下である ${ }^{8)}$ 。

加えて、沖縄県では木造住宅の構造材として使用される木材の素 材生産がほとんど行われていない注8)。そのため、流通する構造材の 価格も他県と比べて高く、スギ正角材の立米単価は東京の約 1.5 倍 である注 9)。一方、RC 造建築に必要な鉄筋やセメントといった建築 資材は沖縄県産資材でほぼ自給が可能な状況にある注10)。

\section{3. 沖縄県の木造住宅生産者の特性と課題 3. 1 事業内容}

調查対象とした工務店 16 社・設計 事務所 4 社の事業内容および木 造住宅事業を開始した経緯を表 2 にまとめた。尚、木造住宅事業と は、工務店については、「元請による木造住宅生産事業」を指し、設 計事務所については、「木造住宅の設計事業」を指す。

\section{(1) 事業エリア}

まず、対象とした工務店・設計事務所 20 社全てが沖縄県内のみで 木造住宅事業を行っている。尚、K02 社は宮崎県の木材流通業者を 母体とした工務店であり、S02 社は茨城県の工務店の協力を受けて 茨城県産材と茨城県の大工を用いた木造住宅供給を行っているが、 この 2 社は支店ではなく独立した事業所である。また、K11 社は埼 玉県の工務店の支店であるが、大工・専門工事業者の確保や技術的 仕様の決定なども本社から独立して行っており、沖縄県のみで活動 する工務店と見なした。

\section{(2) 事業規模}

次に、事業規模について見ると、対象工務店・設計事務所の木造 住宅供給棟数は年間 1 棟から 13 棟であり、比較的小規模な事業所だ と言える。ただし、RC 造住宅生産を木造住宅生産と並行して行い、 合計で年間 30 棟程度の住宅供給を行う工務店は K03 社、K07 社、K09 社の 3 社存在している。

これに対し、全国の工務店を対象とした「平成 17 年度工務店経営 実態調査」（以下、工務店経営実態調查）によると、日本全体では、 年間 0 棟から数千棟まで様々な事業規模の工務店が木造住宅を供給 しており、平均の年間供給棟数は 15 棟程度である注11)。また、日本 の他地域で木質プレハブ住宅を供給している木質プレハブ住宅メー カーも、沖縄県内で活動を確認できたのは 1 社のみであった。また、 その 1 社も沖縄県では木質プレハブ構法ではなく木造軸組構法住宅 を年間 10 棟程度供給している。

また、従業員数を見ても、30 名程度以下と小規模な事業所が多い。 中でも、木造住宅生産に直接関わる木造住宅担当者数注 12$)$ 見ると、 3 名以下の工務店が 16 社中 6 社を占めている。尚、このうち 4 社は 従業員数 6 名以上に対して木造住宅担当者は 1 名のみであり、木造 住宅の年間供給棟数も 1 棟から 3 棟と少ない。

\section{（3）その他の特徵}

このように小規模な木造住宅生産を行う工務店に特徵的であるが、 沖縄県の木造住宅生産者の多くは木造住宅生産とその他の事業を兼 
業で行っている。聞き取り調査から、工務店 16 社について、新築木 造住宅事業が事業所全体の売上に占める割合を見ると、50\%以下の 工務店が 11 社を占める。このうち、K01 社、K03 社はリフォームの 割合が高く、これは木造住宅事業の一環と捉えることもできるが、 他の 9 社は、RC 建設工事業や木材流通業などの売り上げが多くの割 合を占めている。設計事務所 4 社についても、S01、S04 社は木造住 宅に加えて RC 造、鉄骨造の建築・住宅設計を行っている。

その他の特徴的な点として、沖縄県の工務店の多くは設計施工一 貫による木造住宅生産のみを行っていることが挙げられる。対象工 務店 16 社中 9 社が、外部の設計事務所が設計した木造住宅の施工を 行った経験がないと答えた。また、残りの 7 社中 3 社も設計事務所 設計の木造住宅の施工を継続的に行っていないと答えた。これは、 沖縄県における $\mathrm{RC}$ 造住宅生産の多くが設計施工分離によって行わ れている注 13) のとは対照的である。

\section{2 木造住宅事業を開始した経緯}

次に、沖縄県の木造住宅生産者がどのような経緯で木造住宅生産 を開始したかについて述べる。

\section{（1）創業年・木造住宅事業開始時期}

対象工務店・設計事務所 20 社の創業年は 1950 年から 2001 年と戦 後の広い時期に分散している。一方、木造住宅事業を開始した時期 を見ると、1990 年以降に開始した事業所が 20 社中 15 社と大半を占 めている。そのため、法人設立時から木造住宅事業を行っている工 務店は 16 社中 6 社、設計事務所は 4 社中 1 社と半数を下回っており、 近年、他事業から木造住宅事業に進出した事業者が過半を占めてい る。

\section{（2）工務店経営者の出身}

次に、現在の工務店経営者がどのような経緯で工務店経営者とな ったかについて述心゙る。沖縄県の工務店 16 社について、「経営者の 出身注 ${ }^{14)} 」$ 見ると、大工以外の建設業者からの発展・転身した工 務店が 7 社と半数程度を占めている。これは、「工務店経営実態調査」 で、「親または親族からの継承」と「大工・工務店の親方からの独立」 で 6 割程度を占めているのとは対照的である（表 3)。そのため、対 象工務店 16 社で、経営者や木造住宅事業担当者が軸組住宅の大工技 能を有しているのは K01 社 1 社のみであり、枠組壁構法の施工技術 を有しているのも 05 社 1 社のみである。

表 2 対象とした工務店・設計事務所（木造住宅事業開始年順）

\begin{tabular}{|c|c|c|c|c|c|c|c|c|c|c|}
\hline & \begin{tabular}{|c|}
1 \\
事業所 \\
名
\end{tabular} & $\begin{array}{c}\text { (2) } \\
\text { 構法 }\end{array}$ & $\begin{array}{c}\text { (3) } \\
\text { 設立年 }\end{array}$ & 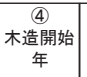 & $\begin{array}{c}\text { (5) } \\
\text { 07年度新築木造棟数 } \\
\text { (その売上全体比) }\end{array}$ & $\begin{array}{c}\text { 6) } \\
\text { 事業エリア }\end{array}$ & $\begin{array}{c}7 \\
\text { 従業員数 } \\
\text { (内数造担当数) }\end{array}$ & $\begin{array}{c}8 \\
\text { 木材購入元 }\end{array}$ & $\begin{array}{c}\text { (9) } \\
\text { 創業時業種 }\end{array}$ & 木造住宅生産を始めた経緯·現在の事業内容の特徵 \\
\hline \multirow{15}{*}{$\begin{array}{l}\text { エ } \\
\text { 務 } \\
\text { 店 }\end{array}$} & K01 & 軸組 & 1978 & 1978 & 5 棟 (40\%) & 本島全域 & 6名 (6名) & 鹿児島 & - & $\begin{array}{l}\text { 木造軸組住宅専門の工務店で木造を学び、その工務店解散を機に独立。 } \\
\text { 他社設計の施エも多く手掛ける。 }\end{array}$ \\
\hline & K02 & 軸組 & 1999 & 1985 & 10 棟 (100\%) & $\begin{array}{c}\text { 本島全域 } \\
\text { 離島 }\end{array}$ & 13名 (4名) & 宮崎 & 木材流通業 & 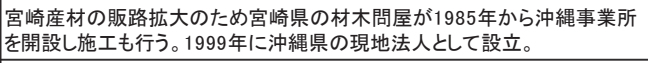 \\
\hline & K03 & \begin{tabular}{c|} 
軸組 \\
枠組壁 \\
\end{tabular} & 1980 & 1989 & 6棟 (20\%) & $\begin{array}{l}\text { 本島全域 } \\
\text { 宮古島 }\end{array}$ & 20名 (一) & $\begin{array}{c}\text { 鹿児島·宮 } \\
\text { 崎 }\end{array}$ & $\begin{array}{l}\text { 店舗内装・リ } \\
\text { フォーム }\end{array}$ & $\begin{array}{l}\text { 内装工事・リフォームから、景気に影響を受けにくく住宅事業へ移行。差別 } \\
\text { 化が可能な木造で熟練技能を必要としない枠組壁構法を選択。 }\end{array}$ \\
\hline & K04 & 軸組 & 1972 & 1989 & 10棟 (40\%) & $\begin{array}{l}\text { 本島全域 } \\
\text { 離島 }\end{array}$ & 14名（5名） & 宮崎 & 木材流通業 & $\begin{array}{l}\text { 材木店として創業。1972年から材エー式で内装工事を開始。利益確保を意 } \\
\text { 図して1989年から木造住宅元請工事も開始。 }\end{array}$ \\
\hline & K05 & 枠組壁 & 1993 & 1993 & 2棟 (40\%) & 本島全域 & 6名 (6名) & 北米 & - & 別会社で枠組壁構法住宅事業に関わり、独立。現在はリフォーム工事の件 \\
\hline & K06 & 軸組 & 1995 & 1995 & 7棟 (50\%) & $\begin{array}{l}\text { 本島全域 } \\
\text { 離島 }\end{array}$ & 16名 (6名) & 宮崎 & 木材流通業 & $\begin{array}{l}\text { 材木店から施工部門として独立。木内装工事を主に手掛けていたが、2005 } \\
\text { 年頃から木造軸組住宅に特化し社名も変更。 }\end{array}$ \\
\hline & K07 & 枠組壁 & 1991 & 1996 & 13棟 (50\%) & 本島全域 & 23名（23名） & カナダ & 不動産 & $\begin{array}{l}\text { バブル崩壊の不動産不況とRC住宅との差別化から木造住宅事業に進出。 } \\
\text { 強度やデザ性から蚻壁構法 }(2 \times 6) \text { 選択。 }\end{array}$ \\
\hline & K08 & $\begin{array}{c}\text { 軸組 } \\
\text { 枠組壁 }\end{array}$ & 1996 & 1996 & 8棟 (85\%) & 本島全域 & 3名 (3名) & $\begin{array}{l}\text { 鹿児島 } \\
\text { 北米 }\end{array}$ & リフォーム & $\begin{array}{l}\text { K03社で木造住宅事業に関わり、リフォーム会社として独立。RC造施工も行 } \\
\text { う。 }\end{array}$ \\
\hline & K10 & 軸組 & 1964 & 1998 & 10棟 (98\%) & 本島中·北部 & 9名 (9名) & 鹿児島 & $\begin{array}{l}\text { 専門工事業 } \\
\text { 建設業 }\end{array}$ & $\begin{array}{l}\text { RC造アパート施工経験もあるが、コスト優位性と他社との差別化を意図して } \\
\text { FCl加盟し木造住宅事業を開始。 }\end{array}$ \\
\hline & K11 & 軸組 & 2001 & 2001 & 5 棟 (90\%) & 本島中·南部 & 4名（4名） & 宮崎 & - & $\begin{array}{l}\text { 首都圏の工務店に勤務後、そこで知った高気密高断熱木造住宅の普及を } \\
\text { 意図して、帰沖。沖縄の工務店でも働いた後、独立。 }\end{array}$ \\
\hline & K12 & 軸組 & 1982 & 2002 & 2棟 (50\%) & 本島中·南部 & 7名（1名） & $\begin{array}{c}\text { 鹿児島·宮 } \\
\text { 崎 }\end{array}$ & 不動産 & $\begin{array}{l}\text { RC 建売を行ってきたが、RC単価が上がり、コスト優位性からFCに加盟し木 } \\
\text { 造住宅事業を開始。 } 5 \text { 年程前から木造に特化。 }\end{array}$ \\
\hline & $\mathrm{K} 13$ & 軸組 & 1950 & 2003 & 1棟 (3\%) & 那覇近郊 & 15名(1名) & 鹿児島 & 建設業 & $\begin{array}{l}\text { 創業時 (1950年) は木造住宅も建設していたが行わなくなる。施主の要求 } \\
\text { の多様化に対応するためFCに加盟し木造住宅事業を開始。 }\end{array}$ \\
\hline & K14 & 軸組 & 1994 & 2005 & 12棟 (70\%) & 本島中·南部 & 10名 (6名) & 鹿児島 & $\begin{array}{l}\text { 建設業 } \\
\text { リフォム }\end{array}$ & $\begin{array}{l}\text { RC改装工事の経験から木造に着目し、FCのHPを見て加盟。HPを見て、他 } \\
\text { 県の建住宅は木造が大多数と知る。 }\end{array}$ \\
\hline & K15 & 軸組 & 1982 & 2006 & 2棟 (20\%) & 本島全域 & 6名 (1名) & 宮崎 & 建設業 & $\begin{array}{l}\text { RC公共工事専門で創業。公共工事減少によって木造住宅によって差別化 } \\
\text { が可能と考え、FC加盟。 }\end{array}$ \\
\hline & K16 & 軸組 & 1996 & 2008 & 2棟 (25\%) & 本島全域 & 3名 (2名) & 鹿児島 & $\begin{array}{l}\text { 専門工事業 } \\
\text { 建設業 }\end{array}$ & 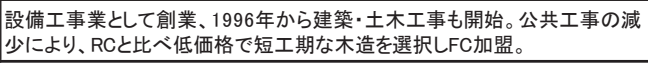 \\
\hline \multirow{2}{*}{$\begin{array}{l}\text { 設 } \\
\text { 計 } \\
\text { 事 } \\
\text { 務 } \\
\text { 所 }\end{array}$} & S01 & 混構造 & 1978 & 1983 & 8棟 (不明) & 本島全域 & 11名 (8名) & 宮崎 & RC設計 & 赤瓦の風景を取り戻すため、木造屋根の混構造住宅を設計開始。 \\
\hline & S04 & \begin{tabular}{c|c} 
軸組 \\
混構造
\end{tabular} & 1995 & - & 1棟 (不明) & 本島全域 & 8名(1名) & 宮崎 & $\mathrm{RC}$ 等設計 & $\begin{array}{l}\text { 温熱環境などの側面に着目しS造、RC造と並行して木造住宅を設計。当初 } \\
\text { 範囲を拡大。 }\end{array}$ \\
\hline
\end{tabular}

注)「(2)構法」は木造住宅で現在事業対象としている構法である。混構造はRC造で屋根のみ木造など。「(4)木造開始年」は木造住宅事業を開始した年。K02社は沖縄支店として1985年から木造住宅事業を行っていたが、現地法人化し

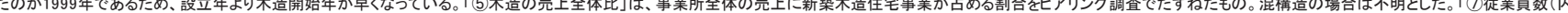
木造担当者数)」の木造担当者数は、木造住宅生産の依頼があった場合にそれに通常関わる人数である。K03社は、時期による变動が大きく不明とした。「9創業事業種」で創業時から木造住宅事業を中心に行っている場合は「一」と した。「10木造住宅生産を始めた経緯·現在の事業内容の特徵しで、多くの回答者から「木造住宅が好きだから、「木造住宅が沖縄の気候に合っている」といった回答が得られたり、他にも様々な回答があったが、ここでは他社と異なる 個別的・特徵的な部分を主に抽出して記載した。 
表 3 経営者の出身注 14

\begin{tabular}{|l|c|c|}
\hline & 沖縄(数) & 全国 \\
\hline 親または親族からの継承 & $0.0 \%(0)$ & $37.7 \%$ \\
\hline 大エ·工務店の親方からの独立 & $25.0 \%(4)$ & $23.9 \%$ \\
\hline 材木店からの発展·転身 & $18.8 \%(3)$ & $3.0 \%$ \\
\hline 材木店·資材流通業者からの発展·転身 & $0.0 \%(0)$ & $1.5 \%$ \\
\hline 不動産·開発業者からの発展·転身 & $12.5 \%(2)$ & $8.1 \%$ \\
\hline 大エ以外の建設業者からの発展·転身 & $43.8 \%(7)$ & $15.9 \%$ \\
\hline その他 & $0.0 \%(0)$ & $9.9 \%$ \\
\hline
\end{tabular}

\section{（3）木造住宅事業選択理由}

対象工務店 16 社に木造住宅事業を選択した理由をたずねたとこ ろ、「木造住宅が沖縄県の環境条件に適している」といった要因に加 えて、「木造住宅が RC 造住宅に比べて安価であること」を要因に挙 げた工務店が 7 社見られた。尚、この 7 社中 6 社は、1998 年以降に 木造住宅事業に進出し、当初からプレカット材を用いた木造住宅生 産を行っている。プレカット技術により、木造住宅が RC 造住宅に対 して価格面で競争力をもったことも、複数の工務店が木造住宅事業 に進出した要因だと考えられる注 15)。また、木造住宅以外の建設業 から木造住宅事業に進出した工務店は、「木内装工事に比べて利益確 保できること」や、「RC 造工事が公共工事の減少などとともに減少 していること」を木造住宅事業進出の理由に挙げた。

\section{3 施工技術者面での課題}

\section{（1）プレカット工法の利用}

沖縄県の木造住宅生産にとって大工の確保は大きな課題であった。 しかし、近年普及したプレカット工法と、木工事について一定の経 験がある型枠大工や木内装大工などの施工技術者が結びつくことに よって、熟練大工を必要とせずに木造住宅の施工を行えるようにな った。さらに、FCやプレカット工場によって大工派遣を含めた様々 な技術指導が沖縄県の工務店に対して行われている。

対象工務店・設計事務所のうち軸組住宅生産を行う 17 社中 16 社 が、プレカット材を用いた住宅生産を行っている。沖縄県の工務店・ 設計事務所、また、宮崎県・鹿児島県のプレカット工場に対する聞 き取り調査から、現在、沖縄県にプレカット材を供給するプレカッ 卜工場は宮崎県・鹿児島県の 4 社（表 4）だと考えられる。

表 4 のプレカット工場 4 社では、沖縄県内の工務店に対して、伏 せ図作成や羽柄材プレカットといった構造材の接合部加工以外の業 務も標準的に行っている。尚、このプレカット工場 4 社では伏せ図 作成や羽柄材プレカットを沖縄県以外の工務店に対しても行ってい るが、P01 社、P03 社が「羽柄材プレカットの適用割合は、沖縄県 以外の工務店に対しては 5,6 割程度である」と答えるなど、全ての 工務店に対して標準的に行うには至っていない。
表 4 調査対象プレカット工場概要

\begin{tabular}{|c|c|c|c|c|c|c|}
\hline & \multicolumn{3}{|c|}{ プレカットエ場の概要 } & \multicolumn{3}{|c|}{ 沖縄県に対する事業 } \\
\hline & $\begin{array}{l}\text { 1) } \\
\text { プレカット } \\
\text { エ場所在地 }\end{array}$ & $\begin{array}{l}\text { (2) } \\
\text { プレカット } \\
\text { 開始時期 }\end{array}$ & $\begin{array}{l}3 \\
\text { プレカット } \\
\text { 年間加工棟数 }\end{array}$ & $\begin{array}{l}\text { (4) } \\
\text { プレカット材 } \\
\text { 供給開始時期 }\end{array}$ & \begin{tabular}{|l} 
5) \\
取引 \\
工務店数
\end{tabular} & $\begin{array}{l}\text { (6) } \\
\text { プレかット } \\
\text { 年間加工棟数 }\end{array}$ \\
\hline P01社 & 宮崎県都城市 & 1991年 & 約1000棟 & 1991年 & 2 社 & 約15棟 \\
\hline P02社 & 宮崎県宮崎市 & 1996年 & 約2000棟 & 1996年 & 2 社 & 約40棟 \\
\hline P03社 & 宮崎県日南市 & 2005年 & 約600棟 & ※1998年頃 & 4 社 & 約15棟 \\
\hline P04社 & 鹿児島県鹿児島市 & 1996年 & 約500棟 & 1998年 & 5 社 & 約35棟 \\
\hline
\end{tabular}

\section{（2）プレカットエ法が普及した経緯}

南九州地域から沖縄県へのプレカット材供給が始まったのは 1991 年だと考えられる。宮崎県から進出した工務店 K02 社は 1985 年から沖縄県で木造住宅供給を行っているが、同グループのプレカ ット工場 P01 社が宮崎県でプレカット材の生産を始めたのが 1991 年であり、当初からこのプレカット材が使われていたと考えられる ためである。

沖縄県に進出する以前から、P01 社グループは九州各県に加えて 首都圏などの大消費地に対してもスギ材供給を行っていた。一方で 当時から、戦後に他林産地で植林された木材が伐採適齢期を迎える と、こうした地域との競争が厳しくなると予想されていた。そこで、 木造住宅が今後増加する余地のある沖縄県への販路拡大を計画し、 沖縄県での木材販売・木造住宅施工を開始した注 ${ }^{16)}$ 。

宮崎県・鹿児島県のプレカット工場に対する聞き取り調査では、 沖縄県が宮崎県・鹿児島県産プレカット材の供給先に適した条件と して、木造住宅が増加する余地が大きいことや、構造材が生産され ておらず木材移入を行う必要があること、スギを構造材として用い るのが一般的で他県のように他産地・他樹種との競争がないこと、 宮崎県・鹿児島県から距離的に近く鹿児島県から沖縄県への輸送船 が毎日出港するなど流通も整っていること、などが挙げられた。

\section{（3）建て方を行う施工技術者の確保}

プレカット工法を用いた場合であっても、その建て方工事を行う 施工技術者は必要である。木造住宅事業の開始時にこうした施工技 術者をどのようにして集めたかを工務店 16 社に対して聞いたとこ ろ、「建て方工事の経験がある沖縄県内の大工・工務店に依頼した」 という回答のほかに、「RC 造建築工事の型枠工事・木内装工事に携 わっていた型枠大工や木内装大工に依頼した」、と答えた工務店が 6 社見られた。

加えて、木造住宅事業を開始した当初の建て方工事に、他県から 大工の派遣を受けた工務店が 3 社見られた。また、宮崎県の大工に 木造住宅の施工を継続的に依頼している K02 社や、建て方工事に茨 城県から大工を呼ぶ S02 社のように、継続的に沖縄県外から大工を 呼び、建て方工事を行う木造住宅生産の事例も見られた。

また、表 4 のプレカット工場 4 社では、沖縄県の工務店に対して、 施工研修や、宮崎県・鹿児島県の大工を紹介・派遣するなどの支援 も行われている。

尚、対象とした工務店のうち、大工を社員大工として正規雇用し ている工務店は 16 社中 3 社にとどまり、沖縄県で大工の育成を積極 的に行っている工務店は少ないと言える。しかし、K02 社、K11 社、 K16 社の 3 社は今後必要な取り組みとして大工育成を挙げており、 K16 社は今後、社員大工を雇用し大工育成を行うと答えている。 


\section{（4）大工以外の施工技術者}

対象とした工務店 16 社に対し、大工以外の施工技術者の確保や施 工精度などの課題があるかをたずねたところ、基礎工事を行う施工 技術者に関する回答が多く見られた。具体的には、木造住宅の基礎 工事を材工一式で請け負う基礎工事業者の少なさや、基礎工事の精 度に対する課題が挙げられた。対象とした工務店 16 社中、「基礎工 事を下請業者に材工一式で発注する」と答えた工務店は 3 社にとど まり、「型枠工事、鉄筋工事、コンクリート打設をそれぞれ別の下請 業者に発注する」という回答が多数を占めた。尚、全国の工務店を 対象とした「工務店経営近代化方策に資する調查・研究」(1995 年) では、「基礎工事を材工一式で下請けに発注する」と答えた工務店が $71 \%$ を占めている注 ${ }^{17)}$ 。

基礎工事について工務店からは、「各工事を別の業者に発注するた め工務店が基礎工事全体を管理する必要がある」といった意見や、 「木造住宅の基礎工事の経験がない業者が型枠工事や打設を行うと、 基礎天端で大きな誤差が出てしまう」といった意見も聞かれた。一 方、1996 年から木造住宅供給を行っている K07 社は、「基礎工事を 継続的に依頼する会社があり、一定量の基䃈工事を経験することで、 基礎の精度などの面での課題はなくなっている。」と答えた。

\section{4 材料}

\section{(1) 木材の移入}

沖縄県内で住宅用構造木材はほとんど素材生産されておらず、沖 縄県の木造住宅生産者は木材を他地域から移入する必要がある。

軸組構法住宅を手がける工務店・設計事務所 17 社のうち、茨城県 産材を用いる 1 社を除いた 16 社は、宮崎県・鹿児島県で加工された プレカット材を用いている。また、枠組壁構法を手がける工務店 4 社中 2 社は沖縄県内の材木店や沖縄県外の商社を通じて木材を購入 しているが、他 2 社は海外と直接木材の取引をしている。

聞き取り調查の結果、木材の輸送費はプレカット材の移入でも海 外からの木材輸入でも建築費全体の 1 2\%程度であり、大きな差は 見られなかった。また、宮崎県・鹿児島県からの木材移出では船輸 送が行われているが、鹿児島県からは毎日コンテナ船が出港してい る。そのため、輸送期間によって他地域に比べて工期が延びる場合 でも、その期間は $1 、 2$ 日程度である。

\section{（2）木造住宅用の部品}

沖縄県では木造住宅着工数が少ないことや他県と離れた地理的な 要因から、木造住宅生産に必要な住宅部品の流通が他県に比べて整 っていない。そのため、プレカット工場 4 社すべてで、構造金物や 樹脂製ねこ土台などの木造住宅用の部品を、プレカット材と合わせ て沖縄県に送る取り組みが行われている。尚、こうした取り組みは 他県の工務店に対しては行われていない。

ただし、プレカット工場への聞き取り調查では、沖縄県内でも木 造住宅用の部品の入手が容易になり、「プレカット工場からこうした 住宅部品を送る必要はなくなりつつある」との回答も得られた。さ らに、「こうした住宅部品の調達は沖縄県内で行った方が、プレカッ 卜工場にとっても個別的・散発的な作業を減らせ、工務店にとって も輸送コストが低減できるなど、工務店・プレカット工場双方にと って利点がある」というプレカット工場の意見も得られた。

プレカット工場による支援が必要なくなりつつあるという変化は、
先述の施工技術者面での支援（建て方時の大工の紹介・派遣）につ いても同様である。今後も沖縄県で一定量の木造住宅生産が継続的 に行われれば、住宅部品の流通や技術者の育成も沖縄県内の住宅生 産者や関連業者によって進められるようになると考えられる。

\section{5 事業開始当初のプレカット材利用有無による工務店の比較}

沖縄県に対するプレカット材移出は 1991 年から始まったと考え られ、1990 年代後半には移出を行うプレカット工場数、プレカット 材を利用する工務店数がともに増加している。木造住宅事業を開始 した当初からプレカット材利用を前提として木造住宅生産を開始し た木造住宅生産者と、プレカット材利用を前提とせずに木造住宅生 産を開始した木造住宅生産者とでは、その事業内容や、事業を開始 した経緯に差が見られるのではないかと考えられる。

そこで本節では、木造住宅事業開始時にはプレカット材を用いず に木造住宅生産を行っていた対象工務店 8 社と、木造住宅事業開始 当初からプレカット材を用いた住宅生産を行っていた 8 社で事業内 容や事業開始の経緯に差が見られるかを比較した（表 5)。尚、前者 は全て 1997 年以前から木造住宅事業を開始しており、後者は全て 1998 年以降に木造住宅事業を開始している。

表 5 事業開始当初のプレカット材利用有無による工務店の比較

\begin{tabular}{|c|c|c|c|}
\hline \multicolumn{2}{|r|}{ 事業内容・木造住宅事業開始の経緯 } & \multicolumn{2}{|r|}{ 工務店数 } \\
\hline \multirow{6}{*}{$\begin{array}{l}\text { 事 } \\
\text { 業 } \\
\text { 容 }\end{array}$} & \multirow{2}{*}{ 枠組壁構法住宅生産を行う } & 4 & $\square$ \\
\hline & & 0 & \\
\hline & \multirow{2}{*}{ 木造住宅事業が売上の50\%以下 } & 4 & $\square$ \\
\hline & & 4 & \\
\hline & \multirow{2}{*}{ 木造担当者5名未満 } & 2 & +2 \\
\hline & & 6 & \\
\hline \multirow{6}{*}{$\begin{array}{l}\text { 事 } \\
\text { 業 } \\
\text { 㜭 } \\
\text { 経 } \\
\text { 緯 }\end{array}$} & \multirow{2}{*}{ FC等加盟と同時に木造住宅事業開始 } & 0 & \\
\hline & & 7 & \\
\hline & \multirow{2}{*}{ コストが木造住宅事業選択理由 } & 1 & $\square$ \\
\hline & & 6 & \\
\hline & \multirow{2}{*}{ 木造以外の建設業から進出 } & 1 & $\square$ \\
\hline & & 6 & \\
\hline & & L & $\begin{array}{l}\text { 当初プレカット以外 (1997年以前) } \\
\text { 当初からプレカット (1998年以降) }\end{array}$ \\
\hline
\end{tabular}

まず、木造住宅事業開始当初からプレカット材利用を行っている 工務店 8 社（1998 年以降に木造住宅事業を開始）では、 RC 造建築工 事などの木造住宅以外の建設業から木造住宅事業に進出した工務店 が 6 社と多くを占める。そして現在でも、こうした以前の事業と兼 業で木造住宅生産を行う工務店が多く、売上に占める木造住宅事業 の割合や従業員に占める木造担当者の割合が低い。また、木造住宅 事業開始に当たって、プレカット工場や F C といった他地域の主体 から施工技術者の派遣や木材以外の住宅部品供給などで多くの支援 を受けており、先述のように木造住宅事業を選択した要因として「コ スト」を挙げた工務店が多く含まれている。

一方、木造住宅事業開始当初はプレカット材を用いない木造住宅 生産を行っていた工務店 8 社（1997 年以前に木造住宅事業を開始） を見ると、このうち 4 社は事業開始当初、枠組壁構法住宅生産を行 っている。この 4 社は 1989 年から 1996 年の間に木造住宅事業を開 始しているが、聞き取り調査では枠組壁構法を選択した理由として、 「沖縄県に軸組構法の施工経験のある大工がいなかった」ことが挙 げられた。現在、この 4 社中 2 社はプレカット材を用いた軸組構法 
住宅生産も行っている。他にも、K06 社はプレカット材が利用可能 になると、それまで行っていた木内装工事をやめて木造住宅元請工 事に特化するなど、木造住宅事業開始当初はプレカット材を用いて いなかった工務店 8 社の事業内容にもプレカット工法の普及は影響 を与えている。

また、プレカット材を利用しない木造住宅生産についてたずねた ところ、枠組壁構法用木材の直接輸入や、沖縄県外での施工研修と いった工務店による主体的な材料入手、職人育成の取り組みが行わ れていた。逆に、材料入手や職人育成が沖縄県内のみでは行いにく かったことが、他の事業所が木造住宅事業に参入する際の阻害要因 になっていたと考えられる。

\section{4. 木造住宅の技術的な特徵}

\section{1 木材}

次に、沖縄県で供給されている木造住宅の技術的特徴について、 木材、基礎、断熱、開口部の 4 点からまとめる。

現在、沖縄県の木造軸組住宅生産の大半には、宮崎県や鹿児島県 でプレカットされた木材が用いられている。そのため、部位毎に用 いられる樹種が宮崎県や鹿児島県の仕様と類似している。具体的に は、スギが土台や横架材にも使われている。軸組構法住宅を手がけ る工務店・設計事務所 16 社 (坪単価などによって土台を使い分ける と答えた工務店 1 社を除く）の標準的な木造住宅の土台、柱、横架 材に使われる樹種を図 2 に示寸。集成材も含めると柱材・横架材は 全てスギであり、土台にも半数以上の工務店で杉が使われている。 これは宮崎県・鹿児島県の仕様に近く注 ${ }^{18)}$ 、日本全体で土台や横架 材にスギを用いる割合が低いのとは対照的である注 19$)$

その他の沖縄県の木造住宅に特徵的な樹種の適用例として、根太 にアピトンをはじめとする南洋材が使われる事例が見られた。根太 にアピトンを現在も用いているのは K09 社 1 社のみであったが、他 にも複数の工務店が、根太にアピトン等の南洋材を用いた経験があ ると答えた。沖縄県ではかつて南洋材の製材が活発に行われており 注 20)、その入手が容易であったためと考えられる。

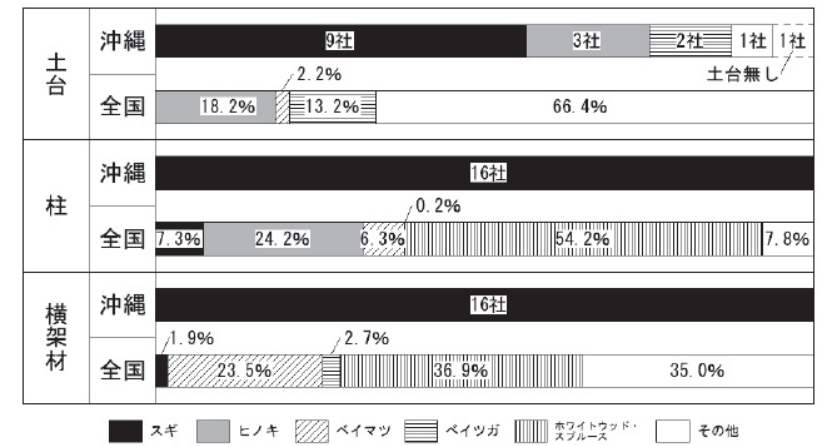

図 2 構造材部位別の樹種注 21)

また、蟻害や湿気対策のために木材へ防蟻防腐処理を施す範囲が、 沖縄県は他地域に比べて広い。他地域では土台や地盤面から高さ 1 $\mathrm{m}$ までの木材に対して、耐久性が高いとされる樹種や防蟻防腐処理 を施した木材を用いる場合が多い。これに対して、沖縄県の工務店 16 社中少なくとも 8 社は垂木などの小屋組羽柄材まで防蟻防腐処理
を行っていた。防蟻防腐種類の方法としては、沖縄県では ACQ 加圧 注入処理が広く行われており、県内に 3 力所の加圧注入処理工場が ある。

\section{2 基礎}

対象とした工務店 16 社全てで、防蟻・防湿や耐震性向上を意図し て、べた基礎が標準的に用いられている。加えて、蟻害対策として、 基礎の外周立ち上がり部から外側に約 $0.5 \sim 1.0 \mathrm{~m}$ の有筋犬走りを 設ける構法が、工務店 16 社中 8 社で使われている。これは K03 社が 開発した構法で、立ち上がり部から地盤までの水平距離を大きくす ることによって、白蟻が躯体に近づきにくくするものである注 22)。 また、べた基礎の底面と犬走り部分のコンクリートを一体で打ち、 立ち上がり部分と犬走り部分との間に割れ目を生じにくくする工夫 も施されている。

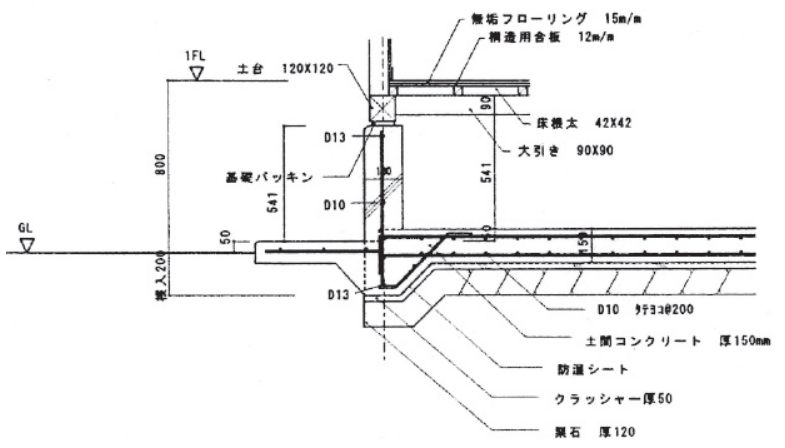

図 3 有筋犬走りの断面

\section{3 断熱}

沖縄県は、次世代省エネルギー基準の地域区分では 6 地域であり、 求められる断熱性能は他地域に比べて高くない。工務店 16 社の断熱 材施工部位を見ると、「屋根・天井」が 16 社中 15 社であり、この 15 社中「屋根・天井・壁」は 8 社、「屋根・天井・壁・床」が 1 社 である。壁に断熱材の施工を標準的に行う工務店は半数程度にとど まるが、沖縄県では強い日射によって屋根面が高温になるため、ほ とんどの工務店が屋根または天井に断熱材を施工している。

また、屋根または天井への断熱材の施工を行わない工務店 1 社も、 野地板に $40 \mathrm{~mm}$ のスギ板を用いることにより、このスギ板の断熱効果 を利用している。野地板に $30 \mathrm{~mm} 40 \mathrm{~mm}$ のスギ板を用いる構法は、 宮崎県の木材流通業者が考案したものであり、断熱効果の他にも、 「内装仕上げを兼衫る」、「釷の効きが良い」、「さ初加工によって雨 漏りしにくい、等の利点があり、少なくとも対象工務店 16 社中 4 社で用いられている。

\section{4 開口部}

建築基準法では、沖縄県の基準風速を全国で最も大きな $46 \mathrm{~m} / \mathrm{s}$ と 規定している。対象工務店 16 社中少なくとも 9 社が開口部の工夫と して、構成材の太い、あるいは水密性・対風圧性の高いサッシを用 いていると答えた。こうした耐久性や水密性の高いサッシに言及し なかった工務店 7 社中 4 社でも、雨戸を取り付けるなどの強風や雨 漏りへの対策が開口部に見られた。

また、水密性・対風圧性の高いサッシを用いると答えた工務店 9 
社中 4 社は RC 造建築用のサッシを木造住宅に使用していた。聞き取 り調査では複数の工務店・設計事務所が、「沖縄県では木造住宅が少 ないために、以前は木造住宅用のサッシが流通しておらず、ほとん どが RC 造建築用のサッシだった」と述べた。 RC 造建築用サッシは、 躯体に埋め込んだアンカーとサッシを溶接で固定するもので、木の 枠材にビスで留めつける木造住宅用サッシとは施工法が異なる。

他にも、沖縄県には複層ガラス製造工場がなく、運搬費が単層ガ ラスに比べて割高になるため、対象とした工務店 16 社のうち複層ガ ラスを標準的に使用寸る工務店は 1 社と、日本全体と比較して複層

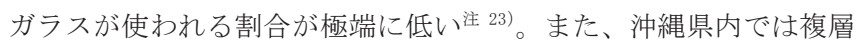
ガラスの修理を行えないため、施主から複層ガラスの使用を要望さ れても反対すると答えた工務店も見られた。

\section{5. 本研究のまとめ·考察}

本研究では、現在、沖縄県で木造住宅生産を行う工務店・設計事 務所を対象とした聞き取り調查・資料収集を行い、彼らの事業内容 や木造住宅生産を行う上での課題、木造住宅の技術的特徴をまとめ た。対象とした木造住宅生産者の 2007 年度の木造住宅着工棟数の合 計は沖縄県全体の 7 割程度を占めており、本研究によって現在の沖 縄県における木造住宅生産の全体的な特徴を具体的に示せたと考え られる。

現在、沖縄県で行われている木造住宅生産は、プレカット工法の 普及から強い影響を受けている。プレカット工法を用いることで、 熟練大工の少ない沖縄県でも、 $\mathrm{RC}$ 造建築施工に携わっていた型枠大 工や木内装大工を利用して木造軸組住宅の施工が可能になった。そ のため、1990 年代後半以降にプレカット工場や FC の支援を受けて 木造住宅事業を開始した工務店が対象工務店の半数程度を占めてお り、木造軸組構法の戸建住宅着工数が増加している。近年、木造住 宅事業を開始した工務店は、当初からプレカット材を用いた住宅生 産を比較的小さな規模で行っており、木造住宅事業開始以前の事業 と兼業で木造住宅生産を行う場合が多い。

また、沖縄県の木造住宅の技術的な特徴とその決定要因・主体に 着目すると、台風や白蟻といった環境要因に加えて、 $\mathrm{RC}$ 造が主流で ある流通システムからの影響や、プレカット材を供給する宮崎県や 鹿児島県からの影響が見られた。さらに、沖縄県に対するプレカッ 卜加工では伏せ図作成や羽柄材加工も標準的に行われており、プレ カット工場が宮崎県・鹿児島県の大工を沖縄県に紹介・派遣したり、 木造住宅に必要な住宅部品をプレカット材と同時に送るなどの特徴 的な支援も見られた。一方で今後、沖縄県で一定量の木造住宅生産 が継続的に行われるようになれば、このような住宅部品の流通や技 術者の育成も沖縄県内の木造住宅生産者やその関連業者によって行 われるようになると考えられる。

本研究は文部科学省 東京大学グローバル COE プログラム「都市空 間の持続再生学の展開」によって行ったものである。また、調査に 当たって、多くの沖縄県の木造住宅産業関係者の方々にご協力をい ただきました。ここに感謝の意を表します。

\section{参考文献}

1）国土交通省総合政策局情報管理部情報安全・調查課建設統計室 : 建築統計 年報

2）藤澤好一ほか：木造住宅の生産組織に関する研究その 1 その 6, 日本建 築学会大会学術講演梗概集（北陸），pp. 1551-pp. 1562，1983.9

3）安藤正雄ほか：地域型木造住宅研究一10 地域調査一その 1 その 5 , 日本 建築学会大会学術講演梗概集（東北）, pp. 1451-pp. 1460， 1982.10

4）石田修一ほか: 地域産材を活用した木造住宅生産プロジェクトの地域間比 較一京都におけるプロジェクト最適化の探求一, 日本建築学会計画系論文 集, 第 73 巻, 第 631 号, pp. 1947-pp. 1952, 2008.9

5）福島駿介ほか: 沖縄における木工系技術及びその伝承に関する研究, 財団 法人新住宅普及会住宅研究所報 No. 12, pp385-pp394，1986.3

6) 菊間満ほか: 復帰 30 年の沖縄県の森林利用と住宅供給、山形大学紀要（農 学），第 14 巻第 2 号, pp. 29-pp. 51、2003.2

7) 沖縄県土木建築部：沖縄県地域木造住宅供給計画, 1996

8）総務省統計局・政策統括官（統計基準担当）・統計研修所：平成 16 年度 事業所・企業統計調査, 2005. 10,

http://www. stat. go. jp/data/jigyou/2004/index. htm, （参照 2008-11-15）

9）建設物価調査会：月刊建設物価 2009 年 4 月号，2009. 3

10) 内閣府沖縄総合事務局開発建設部技術管理課：おきなわ建設経済の動き, 2004.6

11）財団法人住宅保証機構: 平成 17 年度工務店経営実態調査報告書, 2006. 3, http://www. how. or. jp/misc/kanren. html，（参照 2009-05-01）

12) 小倉暢之ほか: 沖縄の市部における建築生産組織の特性に関する研究その 1、日本建築学会大会学術講演梗概集（関東）, E 分冊, pp. 767-pp. 768, 1988.9

13) 日本住宅・木材技術センター：住宅と木材 2008 年 10 月, 2008. 10

14）地域住宅産業研究会: 木造住宅産業一その未来戦略, 彰国社, 1997.7

15) 住宅金融公庫：住宅建築・主要データ調査報告 平成 14 年度 戸建住宅 編，2003. 5

16)服部芳明ほか：木造住宅の需要と供給に関する研究（II）一鹿児島県の大 工・工務店の現状と問題点一, 鹿児島大学農学部学術報告, 第 48 号, pp51-pp59、1998. 3

17) 日本木造住宅産業協会 : プレカットの現況に関する調査, 2005.3

18) 嘉数尚廣 : 沖縄経済 100 年木造産業(3), 琉球新報, 1993 年 10 月 29 日号

19)比嘉武：南風が通る家，さくらパブリッシング，2004.3

20)板硝子協会 : 複層ガラス普及率推移（住宅用）, 2008.4, http://www. itakyo. or. jp/toukei/siryo. html，（参照 2009-03-25）

注

注 1）参考文献 1 より、沖縄県全体の 2007 年度の木造戸建住宅着工数は 146 棟である。沖縄本島の新築木造戸建住宅着工数は、（沖縄県新築木造 戸建住宅着工棟数 $) \times($ 本島の市町村の新築木造建築着工棟数 $) \div($ 沖 縄県全体の木造建築着工棟数）によって推計し、146×164196=122 棟 として計算した。

注 2) 参考文献 1 による。

注 3）参考文献 7 （pp. 15）による。

注 4）参考文献 1 による。

注 5）参考文献 1 による。

注 6）参考文献 1 による。木造戸建住宅戸数から枠組壁構法住宅と木造プレ ハブ工法住宅を差し引いた戸数を軸組構法住宅戸数とした。

注 7）全国の大工技能士数は厚生労働省職業能力開発局、沖縄県の大工技能 士数は沖縄県職業能力開発協会に対するヒアリングによる。

注 8）参考文献 7 （pp. 18-pp. 19）によると、「県内で産出される木材は、住 宅用として利用されることはほとんどないが、琉球松や楠が家具用材 として使用されている。これらの樹種は、希に床や壁用材とされるこ ともあるが、建築材料としては流通していない。（中略）県内で育種 されている木材は建築用材となる、イヌマキ、スギ等であるが、成木 になるのはずいぶんと先のことである。」

注 9）参考文献 9 によると、2009 年 3 月時点のスギ正角 $(3.0 \mathrm{~m} \times 10.5 \times 10.5$ cm）の立米単価は、東京が 38000 円に対して、沖縄は 57000 円である。

注 10) 参考文献 10 (pp44) によると、2002 年度の県産資材構成比は鉄筋が $98.8 \%$ 、セメント（生コン除く）は $79.7 \%$ と高い。

注 11) 平成 17 年度工務店経営実態調査は、住宅保証機構が、住宅保証機構の 登録業者約 12000 社を対象に行ったアンケート調査である。 
注 12)ここで木造担当者とは、従業員のうち、木造住宅の営業、設計、現場 監理、施工を行う者とし、直庸大工を含む。

注 13) 参考文献 12 上ると、那覇市・浦添市・名護市の設計業者、施工業者に 対するアンケート調査では、新築戸建住宅 394 棟のうち $88.8 \%$ が設計 施工分離によって供給されていた。

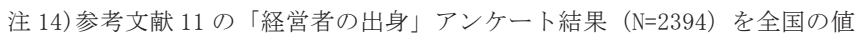
とし、沖縄県の工務店については聞き取り調查結果から参考文献 11 の 質問項目に合わせて集計し直した。参考文献 11 「経営者の出身」の回 答に「親または親族からの継承」や「他業種からの発展・転身」が含 まれていることから、「経営者の出身」とは「現在の工務店経営者が どのような経緯で木造建築工事を請け負う工務店経営者となったか」 を問うものだと解釈できる。このような認識にもとづき、沖縄県の工 務店について、「現在の工務店経営者が、どのようにして木造建築工 事を請け負う工務店の経営者となったか」という観点から、聞き取り 調查結果を基に集計し直している。

注 15) 参考文献 1 により、居住専用住居の工事費予定額を床面積の合計で除 した平米工事単価を算出すると、2006 年度は、全国では木造 15.5 万円、 $\mathrm{RC}$ 造 16.7 万円と $\mathrm{RC}$ 造の方が高いのに対して、沖縄県は木造 15.5 万円、 $\mathrm{RC}$ 造 14.3 万円と木造の方が高い。このように、木造の工事単価が RC 造より高い状況が沖縄県では 1993 年度から 2006 年度まで続いていた。 そして、2007 年度になると、全国は木造 15.6 万円、 RC 造 18.0 万円、 沖縄県は木造 15.4 万円、 RC 造 16.1 万円となり、全国と同様に沖縄県 でも木造の方が R C 造よりも工事単価が低くなった。

注 16）参考文献 13 （pp. 32）によると、K02 社経営者は沖縄県進出の動機とし て、「首都圈や関西方面への出荷は、近い将来、信州や北関東、東北 が林産地としてカをつけてくれば、輸送費等の面から、宮崎県には不 利になることが予想された。一方、地の利を考えると、沖縄は、宮崎 にとって圧倒的に有利な消費地である。木造住宅を普及させ、 1 軒当た りの木材の消費量を増やすことで、沖縄への木材の出荷を増やすこと が可能になる。」と述べている。
注 17) 参考文献 14 のデータは建設省住宅局住宅生産課が 1995 年度に実施し た「工務店経営近代化方策に資する調査・研究」によるものである。 この調查は、住宅保証機構が性能保証住宅登録機構登録業者、全国建 設労働組合総連合加盟工務店、全国中小建築業団体連合会加盟工務店 を合わせた約 11000 社を対象にアンケート調査を行った。この調査で は、基礎工事は、自社施工 $23 \%$ 、材工一式下請 $71 \%$ 、材工分離下請 $6 \%$ であった。

注 18) 参考文献 15 によると、九州地方の管柱の樹種は $64.6 \%$ がスギであるの に対し、日本全体では $27.3 \%$ にどまる（N=3146）。また、参考文献 16 では、鹿児島県内の大工・工務店にアンケート調查を行った結果、 「土台で $47.1 \%$ 、柱（見掛かり）が $89.1 \%$ 、柱（見隠れ）が $90.6 \%$ 、 たるきが $89.9 \%$ 、梁が $69.6 \%$ 、桁が $76.8 \%$ 」などと、鹿児島県におい ては土台や横架材も含めてスギ材が広く使われている。

注 19) 参考文献 17 によると、日本木造住宅産業協会一種会員会社（338 社） を対象とした調查の結果、土台、柱にスギを使う割合は集成材を含め ても、それぞれ $0 \% 、 7.3 \%$ あっあた。

注 20) 参考文献 18 で嘉数は「60 年代から 70 年代にかけては、（中略）南洋 材の製材工場が 50 工場以上稼働するに至った。しかし、その南洋材も 80 年代になると、産地国における資源の減少、原木輸出規制等で輸入 数量が次第に減少し、また県内では住宅建築の低迷もあり、現在では、 わずかに 10 社程度の製材工場が稼㗢している状況である。」と記述し ている。

注 21) 全国の值は参考文献 17 を用いて作成した。また、沖縄の值は工務店数 であるのに対して、全国の值は供給戸数の割合を表している。

注 22)参考文献 19（pp. 32）による。

注 23）参考文献 20 によると、複層ガラス（住宅用）の面積普及率は $80.1 \%$ 、 戸数普及率は $90.4 \%$ である。

(2009年 7 月 5 日原稿受理，2009年 9 月28日採用決定） 